\title{
Serbest Muhasebeci Mali Müşavirlerin Mesleki Etik Algısı: Samsun Örneği
}

\author{
Erdal YILMAZ * \\ Suat YILDIRIM ** \\ Hüseyin Hüsnü BAHAR ***
}

\begin{abstract}
ÖZET
Bu araştırmanın amacı Samsun İlinde bă̆ımsız çalışan muhasebe meslek mensuplarının

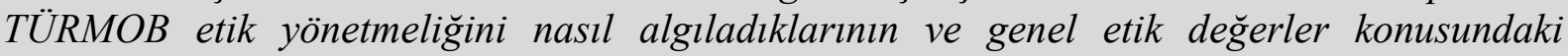
görüşlerinin incelenmesidir. Bu amaçla hazırlanan anket formu Türkiye'de Samsun ilinde uygulanmıştır. Verilerin analizi için betimsel istatistiklere yer verilmiş, kıdem durumuna göre gruplar arası farkları karşılaştırmak için tek yönlü ANOVA testi kullanılmıştır. Sonuç olarak, muhasebe meslek mensuplarının kıdem durumuna göre genel etik alt ölçeği ile ölçek toplam puanlarında kıdemli meslek mensupları lehine anlamlı ölçüde değiştiği tespit edilmiştir. Dürüstlük alt ölçeği ile mesleki yeterlilik ve özen alt ölçek puanlarında kıdem değişkenine göre anlamlı bir farklllık tespit edilememiştir.
\end{abstract}

Anahtar Kelimeler: Etik, Mesleki Etik, Muhasebe, Muhasebe Meslek Mensubu.

JEL Sinıflandirması: M40, M41.

The Perception Of Profession Accountants About Professional Ethics: Samsun Sample

\section{ABSTRACT}

The aim of this study is to investigate how the profession accountants in Samsun perceive the ethics regulations and their general view on general ethics values. The questionnaire form prepared on this purpose has been applied in Samsun, Turkey. Oneway Anova Tests was applied in order to determine the descriptive statistics and the oppositional point of views among groups. As a result, it has been observed that perception of general ethics points and total scale points of senior members is found high than junior members. In addition, according to seniority between members was not founded any difference point of honesty sub scale with professional competence and care sub scale.

Keywords: Ethics, Profession Ethics, Accounting, Accounting Profession.

Jel Classification: M40, M41.

\footnotetext{
*Yrd.Doç.Dr. Erdal Yılmaz, Ondokuz Mayıs Ünviversitesi, Turizm Fakültesi, eyilmaz@omu.edu.tr.

${ }^{* *}$ Doç.Dr. Suat Yıldırım, Erzincan Ünviversitesi, İktisadi ve İdari Bilimler Fakültesi.

${ }^{* * *}$ Doç.Dr. Hüseyin Hüsnü Bahar, Erzincan Ünviversitesi, Eğitim Fakültesi.
} 


\section{GíRiş}

Son yıllarda bilgi ve iletişim teknolojilerindeki çok hızlı gelişmeler toplumların ekonomik, sosyal ve politik yapılarını da etkilemiş ve beraberinde birçok sorunu da getirmiştir. Bu değişim sürecinde iş ve işlemlerin belirli ilke ve kurallar çerçevesinde yürütülmesi, toplumun büyük kesiminin güven duygusunun artırılmasına ve mağduriyetlerinin önlenmesinde önemlidir. Bu bağlamda son yıllarda birçok alanda olduğu gibi muhasebe alanında da etik konusu önemli bir kavram haline gelmiş, çeşitli kurum, kuruluş ve meslek odaları ( üst birlik ) kendi alanları ile ilgili etik değerler ve ilkeleri yayımlamışlardır.

TÜRMOB tarafından "Serbest Muhasebeci Mali Müşavir ve Yeminli Mali Müşavirlerin Mesleki Faaliyetlerinde Uyacakları Etik İlkeler Hakkında Yönetmelik” 19 Ekim 2007 tarihli Resmi Gazete'de yayımlanmıştır. TÜRMOB bünyesinde kurulan Etik Komitesi çalışmalarında, sosyal sorumluluk bilincinin geliştirilmesi, etik değerlere bağlılı̆̆ın sağlanması, rekabet anlayışının daha kaliteli hizmet sunumu biçiminde oluşması, güvenilirlik ve saygınlığının geliştirilmesi, mesleki ilişkilerde etik ilkelere uyumun sağlanması, meslek etiğinin öğretilebilir ve öğrenilebilir olduğundan hareketle, etik eğitimin sağlanması gibi amaçlara erişilmesi hedeflenmiştir (www.turmob.org.tr). Ayrıca, IFAC tarafından yayımlanan ve TÜRMOB tarafından çevirisi yaptırılan muhasebe meslek mensupları için etik kurallar el kitabı 2013 yılında yayınlanmıştır(www.tmud.org.tr).

Etik, etik ilkeler, meslek etiği, etik kodlar, meslek ahlakı, iş ahlakı, etik dış1 davranışlar gibi kavramlar son yıllarda sıklıkla kullanılmaktadır (Altınkurt ve Yılmaz, 2011:113). Etik terimi Yunanca ethos yani "töre" sözcüğünden türemiştir. Değerler felsefesinin (Aksiyoloji) dalı olan etik, felsefenin üç ana dalından biridir: varlık, bilgi ve değer. Doğru davranışı, yanlış davranıştan ayırabilmek amacıyla ahlâk kavramının doğasını anlamaya çalışır. Etiğin batı geleneği zaman zaman ahlâk felsefesi olarak da anılmıştır. Türkçe "ahlak felsefesi" olarak da anıldığ 1 olmuştur. Ayrıca Türkçe'de etik sözcüğü yanlış biçimde ahlâk sözcügüüle eş anlamlı olarak da kullanılır. Etik ile ahlak arasındaki en temel fark, ahlakın toplumsal değerlere dayanırken etiğin evrensel insani değerlere dayanmasıdır. Kısaca etik, evrenseldir. Etik, evrensel kabul gören kurallardır (tr.wikipedia.org). Etik; iyi, kötü, ahlaklı, ahlaksız, erdem ve erdemsizlik gibi değerlerin niteliğiyle uğraşan felsefenin disiplin alanlarından birisidir (Güney, 2004:78).

Arbak (2010:40-41) insan davranışlarını yönlendiren üç temel güçten bahsetmektedir. Bunlar, yasal standartları belirleyen yasalar; kişisel standartları belirleyen kişinin özgür iradesi ve sosyal standartları belirleyen etik'tir. Arbak iş etiğini ise, birey topluluklarının davranışlarını yönlendiren, neyin doğru neyin yanlış olduğuna ilişkin ahlaki ilkeler olarak tanımlamaktadır. İş etiği, iktisadi ve profesyonel faaliyetlerin yerine getirilmesine uyulan standartlar, meslek ve işletme etiğini de kapsamaktadır. Yine Arbak’a göre, etik işletme amaçlarının gerçekleşmesine yönelik bir araç olarak kabul edilebilir. 
Etik, hem bir felsefe disiplinini hem de belli nitelikteki toplumsal kurallar bütününü ifade etmek üzere kullanılmaktadır (Yüksel, 2002:108). Berkman'a (2010:17-18) göre iş etiği, etik ilkeler çerçevesinde iş etiğine uygun davranışların ne olup ne olmayacağıyla ilgili bir husus ve bir alan olduğu şeklinde tanımlanmıştır. İş etiğini daha ziyade sosyolojinin konusu olarak gören Berkman'a göre iş etiği bir ölçüde kültürle ilintili olmakla beraber, meslek etiğinde ortaya konan ilkeler itibariyle toplumsal kültürden daha bağımsız ilkeler olarak ifade edilmektedir. İş etiğini işletmecilik alanları çerçevesinde üretim, pazarlama, denetim ve muhasebe etiği boyutunda görmek de mümkündür.

Köse ve Bektaş (2007: 13-14) etik türlerini üç şekilde sınıflandırmışlardır. Bunlar betimleyici, normatif ve meta etik türüdür. Buna göre betimleyici etik, ahlak alanındaki bilimsel ya da materyalist yaklaşımı tanımlar veya bilimsel yaklaşımın ahlak alanına uygulanmasını ifade etmektedir. Normatif etik, nasıl yaşamamız gerektiğini bildiren ahlaki ilkeleri araştırır; meta etik ise zaman zaman analitik veya eleştirel etik olarak da tanımlanan ve ahlak felsefesinde çağdaş yaklaşımı ifade etmektedir. Mesleki etik konusu daha ziyade etik türlerinden normatif etik grubuna girmektedir (Berkman, 2010:17).

Muhasebe mesleği sadece teknik uzmanlık gerektiren bir meslek olmadığı için mesleğin etik kuralları çerçevesinde yürütülmesi gerekir. En genel anlamıyla etik doğruyu yanlıştan, iyiyi kötüden yararlıyı zararlıdan ayırma ölçütüdür. Meslek etiği, bir meslek grubunu oluşturan bireylerin arasındaki ve toplum ile olan ilişkilerini düzenleyen ilkler ve kuralların bütünüdür (Bilen ve Yılmaz, 2014:70).

Meslek mensupları arasındaki ilişkileri, mesleğin sağlklı bir şekilde yapılması için getirdiği erdemlerin neler olduğunu tanımlayan meslek ahlakı kodları genellikle mesleğin kendi sorunları çerçevesinde o mesleğe mensup kişilerce veya ilgili meslek örgütü tarafindan oluşturulmaktadır (Aydın, 2002: 71). Muhasebe meslek ahlakı ile ilgili olarak Uluslararası Muhasebeciler Federasyonu (IFAC) 1992 yllında Muhasebeciler için Meslek Ahlakı: Eğitimsel Mücadele ve Uygulama adlı yönetmeliği yayınlamıştır. IFAC daha sonra 1998 yılında muhasebe mesleği için Meslek Etiği Kuralları'nı yayınlamıştır.

1992 y1lında TÜSİAD, Francis Mchugh'un Ethics in Business başlıklı kitabını iş ahlakı olarak yayınlamıştır. 1992 yılında TÜGİAD, iş ahlakı ve Türkiye İş Ahlakına Yönelik Tutumlar başlıklı bir rapor yayınlamıştır. 2001 yılında TÜSİAD'ın Görüş dergisinde, dürüstlük, hukuka saygı, çalışma ortamı, çalışanlar, siyasi partililerle ilişkiler, bilgi elde etme, kullanma ve saklamak ve çevre diye altı başlıkta "İş ahlakı ilkeleri" belirtilmiştir (Berkman, 2004:19).

Başbakanlıkla ilişkili, idari özerkliğe sahip bir Üst Kurul olarak Kamu Gözetim Muhasebe ve Denetim Standartları Kurulu (KGK) Kamu Gözetimi alanında uluslararası gelişmelerin gereği olarak yeni Türk Ticaret Kanunu uyarınca öngörülen bağımsız denetim alanını düzenlemek üzere 660 sayılı Kanun Hükmünde Kararname (KHK) ile 2 Kasım 2011 tarihinde kurulmuştur. KGK'nın temel amacı, yatırımcıların çıkarlarını ve denetim 
raporlarının doğru ve bağımsız olarak hazırlanmasına ilişkin kamu yararını korumak ile doğru, güvenilir ve karşılaştırılabilir finansal bilginin sunumunu sağlamaktır. Bu doğrultuda başta borsa şirketleri, bankalar, sigorta şirketleri olmak üzere belirlenen büyük ölçekli şirketlerin denetimlerini gözetmek ve izlemek için kurulmuştur. Uluslararası Muhasebe Standartlarıyla uyumlu Türkiye Muhasebe Standartlarını (TMS) oluşturmak ve yayımlamak, Uluslararası Denetim Standartlarıyla uyumlu Türkiye Denetim Standartlarını (TDS) oluşturmak ve yayımlamak başlıca görevleri arasındadır (www.kgk.gov.tr).

Denetçilik mesleğinin ayırt edici özelliklerinden biri, kamu yararına hareket etme sorumluluğunu kabul etmesidir. Dolayısıyla, bir denetçinin sorumluluğu yalnızca tek bir müşterinin veya işverenin ihtiyaçlarını karşılamak değildir. Denetçi, kamu yararı doğrultusunda hareket ederken Etik Kuralları gözetir ve bu Kurallara uyar. Ayrıca, Denetçi, mesleki bir faaliyeti üstlenirken bir çıkar çatışmasıyla karşı karşıya kalabilir. Çıkar çatışması, tarafsızlık için bir tehdit oluşturmasının yanı sıra diğer temel ilkelere yönelik tehditler de oluşturabilir. (www.kgk.gov.tr).

Son y1llarda yaşanan olumsuz gelişmeler toplumun her alanında olduğu gibi muhasebe mesleğinde de etik ve güven tartışmalarını gündeme getirmiştir. Herhangi bir mesleğin ifasında meslek elemanları mesleki etiğe ne kadar bağlı kalırlarsa o mesleğe olan güven ve saygınlık o kadar artacaktır. Muhasebe bir bilgi sistemidir. Sunulan bilgilerin doğru ve güvenilir olması olumlu kararların alınmasına yardımcı olacak bu da kaynakların verimli ve adil kullanımını sağlayacaktır. Meslek mensubu, devletten topluma, mesleki kuruluşlardan müşterilere kadar çok geniş bir alanda sorumlulukları olan kişidir. Edindiği bilgi ve deneyimini, bunu talep edenlere muhasebe mesleği ile ilgili yasaların ve mesleki kuruluşların öngördüğü sınırlar ve açıklamalar çerçevesinde sunmalıdır. Meslek mensubu bu görevi yerine getirirken zaman zaman ahlak kurallarıyla çelişkiye düşebilir. $\mathrm{Bu}$ problemleri gidermede mesleğin gerektirdiği meslek etiği önemli bir rol oynar (Bilen ve Yılmaz, 2014:59).

Bu noktadan hareketle bu çalışmada Türkiye'de muhasebe meslek etiğine yönelik yapılan düzenlemeler ve meslek mensupları tarafindan nasıl algılandığı araştırılmıştır. Öncelikle meslek mensuplarında etik konusu irdelenmiş, daha sonrada Samsun'da faaliyet gösteren muhasebe meslek mensuplarına bu konuda bir anket araştırması yapılmıştır.

\section{LITERATÜR}

Sakarya ve Kara'nın (2010) etik ile ilgili olarak yaptıkları anket araştırmasından şu sonuçlar çıkarılmıştır: Muhasebe meslek mensuplarının etik algılamalarının cinsiyete göre karşılaştırılması sonucunda genel olarak etik algılamada bir farklılık olduğu; eğitim düzeyine göre yapılan karşılaştırmada meslek mensuplarının dürüstlük, tarafsızlık, mesleki yeterlilik ve özen, gizlilik, mesleki davranış ve genel olarak etik algılaması değişkenleri ile ilgili meslek etiğine ilişkin algılamalarında herhangi bir farklılık bulunmadığı; unvana göre yapılan 
karşılaştırma sonucunda meslek mensuplarının unvanları ile dürüstlük ve mesleki davranış değişkeni arasında anlamlı farklılıkların bulunduğu tespit edilmiştir.

Sakarya ve Kara'ya göre "Genel olarak meslek etiği ile ilgili değişkenler arasındaki ilişkinin incelenmesi sonucunda değişkenlerin çoğu arasında ( $\alpha=0,05$ önem düzeyinde) anlamlı ve pozitif yönlü ilişki olduğu ancak korelasyon katsayılarının $0,5^{\prime}$ 'in altında olması nedeniyle değişkenler arası ilişkilerin yüksek düzeyde olmadı̆̆ı, ancak dürüstlük ile tarafsızlık, mesleki yeterlilik ve özen, gizlilik ve genel olarak etik algılaması değişkenleri arasında anlamlı ve pozitif yönlü bir ilişki olduğu ortaya çıkmıştır.

Akın ve Özdaşlı (2014), yaptıkları bir araştırmada, muhasebe eğitimi alan öğrencilerin muhasebe mesleğini icra eden meslek erbabına kıyasla dürüstlük ve şeffaflık ilkelerinin meslek mensupları tarafından daha fazla ihlal edildiğini düşündükleri ortaya çıkmıştır.

Yalçın'ın (2011) çalışmasından elde edilen bulgular, bağımsız çalışan muhasebe meslek mensupları ve işletmelerin Birlik tarafından, dürüstlük, tarafsızlık, mesleki yeterlilik ve özen, gizlilik ve mesleki davranış olarak belirlenen temel etik ilkeler konusunda sunulan ifadelere, bazı ifadelerde iki grup arasında farklılık tespit edilmesine rağmen, genelde katılım yönünde tutum ifade ettiklerini göstermiştir.

Kısakürek ve Alpan'a (2010) göre, Sivas ilinde meslek mensuplarına yaptıkları araştırmada, $\mathrm{AB}$ uyum sürecinin meslek etiğinin gelişmesine "katılıyorum" diyenler \% 75 oranında bulunmuştur. Ayrıca meslek mensupları, meslek etiğinin gelişmesinin genel ekonomik gelişimine \% 25 oranında katılmaktadır.

Yıldız'ın (2010) Kayseri ilinde yaptığı araştırmada, meslek mensuplarının muhasebede meslek etik konusunu önemsemekte ve bu konuda eğitim gerekliliğine \% 97 oranında katılmakta olduğu görülmektedir. Ayrıca, araştırmada meslek mensuplarını etik dışı davranmalarına sebep olan birinci derecede önemli baskı grubunun mükellefler olduğu tespit edilmiştir.

Landry, Moyes ve Cortes (2004:102-108) muhasebe mesleğine yönelik eğitim alan ve almayan, erkek ve bayan İspanyol öğrencilerin etik algılamaları ve farklılıkları analiz etmeye yönelik araştırmalarında; mesleki eğitime yoğunlaşanlar arasında 21, cinsiyet açısından da 18 önemli farklılık tespit etmişlerdir.

\section{TÜRKIYE'DE MUHASEBE ETIK İLKELERI}

2001'de TÜRMOB tarafından "Mecburi Meslek Kararları" yayınlamıştır. Bu kararda 3568 sayılı Kanun'a göre ruhsat almış Serbest Muhasebeci, Serbest Muhasebeci Mali Müşavir ve Yeminli Mali Müşavirlerin taşımaları gereken asgari nitelikler, yasal davranışları ve sorumlulukları 3568 sayılı Yasa ile bu Yasa'ya dayanılarak çıkarılan Yönetmeliklerle düzenlenmiştir. Bu mecburi meslek kararlarının amacı, yasal gerekleri aşan ölçüde meslek mensuplarının kendilerini kontrol etmeleri amacıyla moral ilkeler sistemini, toplum, müşteriler ve diğer meslek mensuplarıyla ilişkilerde uyulması gereken ve yerine getirilmesi gereken kuralları içermektedir (turmob.org.tr). Mecburi meslek kararlarında meslek ahlakı 
"Ruhsatlı meslek mensuplarının yeterlilik, güvenilirlik, tarafsızık, bağımsız karar alabilme, kendi kendilerini denetlemelerinin ve dürüstlügünün simgesi” olarak belirtilmiştir. Mesleki ahlak kuralları, bu mesleki kararda tanımlanan meslek ahlakı anlayışını benimseyen ruhsatlı meslek mensuplarını yücelttiği gibi alçaltıcı tutum ve davranışlara karşı da korumaktadır. $\mathrm{Bu}$ karar incelendiğinde, muhasebe meslek mensuplarının mesleki uzmanlık, dürüstlük, tarafsızlık, güvenilirlik, mesleki özen ve titizlik, muhasebe ilkelerine ve standartlara uyma zorunluluğu ile sır saklama ilkeleri yükümlülüğü yer almaktadır.

TÜRMOB tarafindan 19.10.2007 tarihinde "Serbest Muhasebeciler, Serbest Muhasebeci Mali Müşavirler ve Yeminli Mali Müşavirlerin Mesleki Faaliyetlerinde Uyacakları Etik İlkeler Hakkında Yönetmelik" (Etik Yönetmeliği), 26675 sayılı Resmi Gazete'de yayımlanmıştır. Söz konusu etik ilkelerin çıkarılmasının hedefi, tüm üyeleri en üst derecede mesleki bilgiye sahip, sosyal sorumluluk bilinci olan, etik değerlere bağl1, rekabet anlayışı daha kaliteli hizmet sunumu biçiminde sunulmuş, güvenilir ve saygın bir meslek mensupları kitlesi oluşturmaktır. Bu ilkeler, muhasebe meslek mensuplarının mesleki ilişkilerinde uymaları gereken asgari etik ilkeler olarak belirtilmiştir (TÜRMOB Yayınları330:283).

3568 sayılı Yasaya göre, meslek unvanına sahip olan, bağımsız veya bağımlı olarak çalışan tüm meslek mensupları ile bunların oluşturduğu şirketlerin faaliyetleri, etik yönetmeliği kapsamındadır (TURMOB Yayınları-330:283).

Etik yönetmeliğine göre, tüm meslek mensuplarının uyacakları temel etik ilkeleri dürüstlük, tarafsızlık, mesleki yeterlilik ve özen, gizlilik ve mesleki davranış olarak sınıflandırılmıştır. Bunlar kısaca şöyle açıklanabilir (TÜRMOB Yayınları-330:296 ve TÜRMOB Yayınları:457):

Dürüstlük, meslek mensuplarının tüm mesleki ve iş ilişkilerinde doğru sözlü ve dürüst davranmalarıdır.

Tarafsızlık, yanlı ve ön yargılı davranarak; üçüncü kişilerin haksız ve uygunsuz biçimde yaptıkları baskıların meslek mensuplarının mesleki kararlarını etkilememesi veya engellememesidir.

Mesleki yeterlilik ve özen, meslek mensubunun mesleki faaliyetlerini yerine getirirken teknik ve mesleki standartlara uygun olarak, özen ve gayret içinde davranmasıdır.

Gizlilik, meslek mensubunun iş ilişsileri sonucunda elde ettiği bilgileri açıklamasını gerektirecek bir hak veya görevi olmadıkça üçüncü kişi veya gruplara açıklamaması ve bu tür bilgilerin meslek mensubunun veya üçüncü kişilerin çıkarları için kullanmamasıdır.

Mesleki davranış ise meslek mensubunun mevcut yasa ve yönetmeliklere uymasını ve mesleğin itibarını zedeleyecek her türlü davranıştan kaçınmasını ifade etmektedir.

\section{ARAŞTIRMANIN AMACI}

Son yıllarda yaşanan olumsuz gelişmeler toplumun her alanında olduğu gibi muhasebe mesleğinde de etik ve güven tartışmalarını gündeme getirmiştir. Amerika ve Avrupa'daki 
Enron, HYCO, Worldcom, büyük şirketlerdeki yönetim skandalları etik ve özellikle denetim konularının önemini artırmaktadır. Bu bağlamda her türlü muhtemel muhasebe ve denetim sorunlarının çözümü için Amerika Birleşik Devletleri'nde Sarbanes-Oxley Yasası çıkarılmıştır (Berkman, 2004:18-19). Bu araştırmanın amacı, Samsun İlinde bağımsız çalışan muhasebe meslek mensuplarının TÜRMOB etik yönetmeliğini nasıl algıladıklarının belirlenmesi ve genel etik değerler konusundaki görüşlerinin incelenmesidir. Bağımsız çalışan meslek mensuplarının uyacakları etik ilkelere göre; bağımsız çalışan meslek mensubu dürüstlüğe, tarafsızlığa ve mesleğin adına zarar verebilecek ve sonucunda meslekî hizmetlerin yerine getirilmesi ile bağdaşmayacak herhangi bir iş ya da faaliyete katılmamalıdır (www.asmmmo.org.tr). Söz konusu amaç doğrultusunda Samsun ilinde faaliyet gösteren serbest muhasebeci mali müşavirlere bu konuda bir anket uygulanmıştır. Bu çalışmada meslek mensuplarının meslek etiği algısı incelenmiştir.

\section{ARAŞTIRMANIN YÖNTEMI}

Araştırmada veri toplama aracı olarak anket tekniği kullanılmıştır. Anket formunda 3568 say11 yasa kapsamında Resmi Gazete'de 19.10.2007 tarihinde "Serbest Muhasebeciler, Serbest Muhasebeci Mali Müşavirler ve Yeminli Mali Müşavirlerin Mesleki Faaliyetlerinde Uyacakları Etik İlkeler Hakkında Yönetmelik” yayımlanmıştır. Bu yönetmeliğe göre, temel etik ilkeleri dürüstlük, tarafsızlık, mesleki yeterlilik ve özen, gizlilik ve mesleki davranış olarak sınıflandırılan etik ilkelerinden oluşturulan 5 boyut kullanılmıştır. Söz konusu ölçeğin oluşturulmasında Sakarya ve Kara'nın (2010) “Türkiye'de Muhasebe Meslek Etiğine Yönelik Düzenlemeler ve Meslek Mensupları Tarafından Algılanması Üzerine Bir Alan Araştırması" isimli makaleden de yararlanılmıştır.

Araştırmanın ana kütlesini Türkiye'de Samsun ilinde faaliyet gösteren bağımsız çalışan, serbest muhasebeci mali müşavir ve yeminli mali müşavirler oluşturmaktadır. Şu an itibariyle, 140 kişi serbest muhasebeci, 658 kişi serbest muhasebeci mali Müşavir olarak kayıtlı gözükmektedir (www.Türmob.org) . 2014 Haziran- 2014 Temmuz döneminde Samsun ilinde 500 adet anket formu muhasebe meslek mensuplarına doldurulmak üzere gönderilmiş ve daha sonra geri alınmıştır. Çalışmalar sonunda geri dönen kullanılabilir anket sayıları 245 'tir. Bunlardan 5 tanesi yeminli mali müşavirlere aittir. Bu sayı düşük çıktığı için veri setinden çıkarılarak sadece 239 adet serbest muhasebeci mali müşavir anketi değerlemeye alınmıştır.

Muhasebe meslek etik ölçeği, 5 boyutu ile alınmış, 1-5. sorularda dürüstlük boyutunu, 6-10. sorularda tarafsızlik boyutunu, 11-15. sorularda mesleki yeterlilik ve özen boyutunu, 16-20. sorularda gizlilik boyutunu, 21-25. sorularda mesleki davranış boyutunu, 26-35. sorularda genel olarak etik algılaması boyutunun ortaya çıkarılması amaçlanmıştır.

Ölçeklerde yer alan ifadelerin yanıtları için beş aralıklı likert tipi ifade kullanılmıştır. Örneğin, "ülkemizde meslek mensuplarının etik ilkeleri uygulamada yeterli özeni gösterdiğini düşünüyorum” ifadesinin yanıtı için "1-Kesinlikle katılmıyorum”, "2-Katılmıyorum”, "3Kararsızım”, "4-Katılıyorum”,"5-Kesinlikle katılıyorum” gibi beş seçenek bulunmaktadır. 
Buna ilaveten, meslek mensuplarının demografik yapısını incelemek amaciyla 2 soru sorulmuştur. Toplanan verilerin analizi için betimsel istatistiklere yer verilmiş, kıdem durumuna göre gruplar arası farkları karşılaştırmak için tek yönlü ANOVA testi kullanılmıştır.

\section{ARAŞTIRMANIN BULGULARI}

Veriler 2014 y1lı yaz döneminde 239 serbest muhasebeci ve mali müşavirden elde edilmiştir.

Katılımcıların mesleki kıdemine göre frekans ve yüzdeleri Tablo 1'de gösterilmiştir. Mesleki kıdemi 1-5 yıl olan \%14, 6-10 yıl olan \%22, 11-15 y1l olan \%29, 16 yıl ve üzeri olan $\% 35$ olarak bulunmuştur.

Tablo 1: Katılımcıların Mesleki Kıdem Durumuna Göre Frekans ve Yüzdelik Dağılımları

\begin{tabular}{lcc}
\hline & Frekans & Yüzde \\
\hline $1-5$ Y11 (A) & 33 & 13,8 \\
$6-10$ Y11 (B) & 54 & 22,6 \\
$11-15$ Y11 (C) & 69 & 28,9 \\
16 Y1l ve Üzeri (D) & 83 & 34,7 \\
Toplam & 239 & 100,0 \\
\hline
\end{tabular}

Tablo 2'de muhasebe meslek etik ölçek ve alt ölçeklerin güvenirlik katsayıları gösterilmiştir. Dürüstlük alt ölçeği .64, tarafsızlık .27, mesleki yeterlilik ve özen .50, gizlilik .39 , mesleki davranış .26, genel olarak etik ölçeği ise .69 , ölçek toplamı ise .76 olarak bulunmuştur.

Tablo 2: Muhasebe Meslek Etik Ölçek ve Alt Ölçeklerine İlişkin Güvenirlik Katsayilar1

\begin{tabular}{lcc}
\hline Alt Ölçek & Madde Sayısı & Cronbach's Alpha \\
\hline Dürüstlük & 5 & .64 \\
Tarafsızlık & 5 & .27 \\
Mesleki Yeterlilik ve Özen & 5 & .50 \\
Gizlilik & 5 & .39 \\
Mesleki Davranış & 5 & .26 \\
Genel Olarak Etik & 10 & .69 \\
Ölçek Toplamı & 35 & .76 \\
\hline
\end{tabular}


Ölçeğin dürüstlük, genel etik ve ölçek toplam puanlarına ilişkin güvenirlik katsayılarının kabul edilebilir düzeyde olduğu görülmektedir. Ancak tarafsızlık, gizlilik ve mesleki davranış alt ölçek güvenirlik katsayıları düşük bulunduğundan, bu alt ölçeklere ilişkin analizler yapılmamıştır. Mesleki yeterlilik ve özen alt ölçeğine ilişkin güvenirlik katsayısı düşük olmakla birlikte, yine de çalışmada gösterilmesinin faydalı olacağı düşüncesi ile ilgili analizler yapılmıştır.

\subsection{Dürüstlük Bulguları}

Tablo 3'te mesleki kıdem durumuna göre dürüstlük alt ölçek puan ortalamaları gösterilmiştir. Tabloya bakıldığında dürüstlük puanları 16,6970-17,2778 arasında olup, ortalama puan 17,0126 olarak tespit edilmiştir.

Tablo 3: Mesleki Kıdem Durumuna Göre Dürüstlük Alt Ölçek Puanlarına İlişkin Betimleyici İstatistikler

\begin{tabular}{lccc}
\hline & $\mathrm{N}$ & $\bar{X}$ & Ss \\
\hline 1-5 Y11 (A) & 33 & 16,6970 & 4,06575 \\
6-10 Y11 (B) & 54 & 17,2778 & 3,62599 \\
11-15 Y11 (C) & 69 & 17,1739 & 3,36922 \\
16 Y11 ve Üzeri(D) & 83 & 16,8313 & 3,42807 \\
Toplam & 239 & 17,0126 & 3,53432 \\
\hline
\end{tabular}

Tablo 4'te mesleki kıdem durumuna göre dürüstlük alt ölçek puanlarına ilişkin tek yönlü ANOVA Testi sonuçları gösterilmiştir.

Tablo 4: Mesleki Kıdem Durumuna Göre Dürüstlük Alt Ölçek Puanlarına İlişkin Tek Yönlü ANOVA Testi Sonuçları

\begin{tabular}{lccccc}
\hline $\begin{array}{l}\text { Varyansın } \\
\text { Kaynağ1 }\end{array}$ & $\begin{array}{c}\text { Kareler } \\
\text { Toplamı }\end{array}$ & Sd & Ortalaması & $\mathrm{F}$ & $\mathrm{p}$ \\
\hline Gruplar Aras1 & 11,608 & 3 & 3,869 &, 307 &, 820 \\
Grup İçi & 2961,355 & 235 & 12,602 & & \\
Toplam & 2972,962 & 238 & & & \\
\hline $\mathrm{p}>.05$ & & & & &
\end{tabular}

Mesleki kıdemin muhasebe elemanının dürüstlük algısını etkilemediği görülmektedir (F3-235: .307, $\mathrm{p}>$.05). Yani, kıdemli birisiyle kıdemsiz birisinin dürüstlük algısı arasında anlamlı bir farkl1lık yoktur. 


\subsection{Mesleki Yeterlilik Bulguları}

Tablo 5'te mesleki kıdem durumuna göre mesleki yeterlilik ve özen alt ölçek puanları ortalamaları gösterilmiştir. Tabloya bakıldığında mesleki yeterlilik ve özen puanları 16,424217,9565 arasında olup, ortalama puan 17,5565 olarak tespit edilmiştir.

Tablo 5: Mesleki Kıdem Durumuna Göre Mesleki Yeterlilik ve Özen Alt Ölçek Puanlarına İlişkin Betimleyici İstatistikler

\begin{tabular}{lccc}
\hline & $\mathrm{N}$ & $\bar{X}$ & Ss \\
\hline $1-5$ Y1l (A) & 33 & 16,4242 & 2,64611 \\
6-10 Y1l (B) & 54 & 17,9074 & 3,11581 \\
$11-15$ Y11 (C) & 69 & 17,9565 & 3,60325 \\
16 Y11 ve Üzeri (D) & 83 & 17,4458 & 2,85953 \\
Toplam & 239 & 17,5565 & 3,14428 \\
\hline
\end{tabular}

Tablo 6'da mesleki kıdem durumuna göre mesleki yeterlilik alt ölçek puanlarına ilişkin tek yönlü ANOVA Testi sonuçları gösterilmiştir.

Tablo 6: Mesleki Kıdem Durumuna Göre Mesleki Yeterlilik Alt Ölçek Puanlarına İlişkin Tek Yönlü ANOVA Testi Sonuçları

\begin{tabular}{lrrrrr}
\hline $\begin{array}{l}\text { Varyansın } \\
\text { Kaynağ }\end{array}$ & $\begin{array}{c}\text { Kareler } \\
\text { Toplamı }\end{array}$ & \multicolumn{1}{c}{ Sd } & Ortalaması & \multicolumn{1}{c}{$\mathrm{F}$} & $\mathrm{p}$ \\
\hline Gruplar Aras1 & 61,014 & 3 & 20,338 & 2,085 &, 103 \\
Grup İçi & 2291,973 & 235 & 9,753 & & \\
Toplam & 2352,987 & 238 & & & \\
\hline $\mathrm{p}>.05$ & & & & &
\end{tabular}

Kıdem durumuna göre muhasebe elemanlarının mesleki yeterlilik ve özen algısının değişmediği Tablo 6'da görülmektedir (F3-235: 2.085, p > .05).

\subsection{Genel Etik Bulguları}

Tablo 7'de mesleki kıdem durumuna göre genel etik alt ölçek puanlarının ortalamaları gösterilmiştir. Tabloya bakıldığında genel etik puanları 30,9394-34,6867 arasında olup, ortalama puan 33,4310 olarak tespit edilmiştir. 
Tablo 7: Mesleki Kıdem Durumuna Göre Genel Etik Alt Ölçek Puanlarına İlişkin Betimleyici İstatistikler

\begin{tabular}{lccc}
\hline & $\mathrm{N}$ & $\bar{X}$ & Ss \\
\hline 1-5 Y11 (A) & 33 & 30,9394 & 7,26266 \\
6-10 Y11 (B) & 54 & 32,5370 & 5,91038 \\
11-15 Y11 (C) & 69 & 33,8116 & 4,79974 \\
16 Y11 ve Üzeri (D) & 83 & 34,6867 & 5,38274 \\
Toplam & 239 & 33,4310 & 5,75063 \\
\hline
\end{tabular}

Mesleki kıdem durumuna göre genel etik algısı alt ölçek puanlarına ilişkin tek yönlü ANOVA Testi sonuçları Tablo 8'de gösterilmiştir.

Tablo 8: Mesleki Kıdem Durumuna Göre Genel Etik Algısı Alt Ölçek Puanlarına İlişkin Tek Yönlü ANOVA Testi Sonuçları

\begin{tabular}{lcccccc}
\hline $\begin{array}{l}\text { Varyansın } \\
\text { Kaynağ1 }\end{array}$ & $\begin{array}{c}\text { Kareler } \\
\text { Toplamı }\end{array}$ & Sd & Ortalaması & F & p & Tukey \\
\hline Gruplar Aras1 & 388,900 & 3 & 129,633 & 4,072 &, $008^{*}$ & A-D \\
Grup İçi & 7481,711 & 235 & 31,837 & & & \\
Toplam & 7870,611 & 238 & & & & \\
\hline p $<.01$ & & & & & &
\end{tabular}

Tek yönlü ANOVA analizi ile mesleki kıdem durumuna göre muhasebe meslek elemanlarının genel etik algısı alt ölçek puan ortalamalarının anlamlı farklılık gösterdiği tespit edilmiştir (F3-235: 4.072, $\mathrm{p}<.01$ ). Tukey HSD Testi sonuçları, anlamlı farkın A ve D grupları arasında olduğunu göstermektedir. Burada 1-5 y1l kıdemi olan meslek mensuplarının genel etik algısı ortalaması Tablo 7'ye göre 30,9394 iken 16 Yıl ve üzeri kıdemi olan meslek mensupları 34,6867 olduğu tespit edilmiştir. Buna göre 1-5 y1l kıdemi olan meslek mensuplarının genel etik algısı 16 Y11 ve üzeri faaliyet gösteren meslek mensuplarına nazaran düşük olduğu gözlemlenmiştir.

\subsection{Muhasebe Meslek Etik Puan Ortalamaları}

Tablo 9'da mesleki kıdem durumuna göre muhasebe meslek etik toplam puanları ortalamaları gösterilmiştir. Tabloya bakıldığında meslek etiği toplam puanları 116-123,9275 arasında olup ortalama puan 122,1255 olarak bulunmuştur. 
Tablo 9: Mesleki Kıdem Durumuna Göre Muhasebe Meslek Etik Toplam Puanlarına İlişkin Betimleyici İstatistikler

\begin{tabular}{lccc}
\hline & N & $\bar{X}$ & Ss \\
\hline 1-5 Y11 (A) & 33 & 116,0000 & 12,00521 \\
6-10 Y11 (B) & 54 & 121,7963 & 11,93596 \\
11-15 Y11 (C) & 69 & 123,9275 & 13,23800 \\
16 Y11 ve Üzeri (D) & 83 & 123,2771 & 12,60402 \\
Toplam & 239 & 122,1255 & 12,74907 \\
\hline
\end{tabular}

Tablo 10'da mesleki kıdem durumuna göre muhasebe meslek etik toplam puanlarına ilişkin tek yönlü ANOVA sonuçları gösterilmiştir.

Tablo 10: Mesleki Kıdem Durumuna Göre Muhasebe Meslek Etik Toplam Puanlarına İlişkin Tek Yönlü ANOVA Testi Sonuçları

\begin{tabular}{lcccccc}
\hline $\begin{array}{l}\text { Varyansın } \\
\text { Kaynağı }\end{array}$ & $\begin{array}{c}\text { Kareler } \\
\text { Toplamı }\end{array}$ & $\mathrm{Sd}$ & $\begin{array}{c}\text { Kareler } \\
\text { Ortalamas1 }\end{array}$ & $\mathrm{F}$ & $\mathrm{p}$ & Tukey \\
\hline Gruplar Aras1 & 1578,211 & 3 & 526,070 & 3,332 &, $020^{*}$ & A-C, A- \\
Grup İçi & 37106,023 & 235 & 157,898 & & & D \\
Toplam & 38684,234 & 238 & & & \\
\hline
\end{tabular}

p $<.01$

Tablo 10'a göre, mesleki kıdem durumuna göre, 1-5 y1l ile 11-15 yıl kıdemliler arasında alt ölçek puan ortalamalarının anlamlı farklılık gösterdiği tespit edilmiştir (F3-235: 3,332, $\mathrm{p}<.05)$. Aynı şekilde, 1-5 yıl kıdemi olanla, 16-üzeri kıdemi olanlar arsında alt ölçek puan ortalamaları arasında anlamlı bir farklılık tespit edilmiştir.

\section{SONUÇLAR}

Muhasebenin temel görevi, paydaşlarının doğru karar vermelerini sağlamak üzere doğru ve güvenilir bilgiler üretmektir. Bilgiye ihtiyaç duyan işletmeyle ilgili taraflara muhasebe bilgi sisteminden çıkan bilgiler ülke kaynaklarının da etkili ve verimli kullanılmasını sağlayacaktır.

Son yıllarda dünyada yaşanan muhasebe ve denetim skandalları muhasebe mesleğinde etik konusunu gündeme getirmiştir. Bu nedenle Türkiye'de muhasebe mesleğinde etikle ilgili yasal düzenlemeler yapılmıştır. 2001 yılında TÜRMOB başkanlığ 1 tarafından mesleki ahlak kurallarıyla ilgili Mecburi Meslek Kararı ve 2007 yılında ise muhasebe meslek mensupları için mesleki faaliyetlerinde uyacakları etik yönetmeliğini Resmi Gazete'de yayımlanmıştır. 
Samsun ilindeki muhasebe meslek mensuplarının mesleki etik algısının ölçülmesinin amaçlandığı bu çalışmada elde edilen sonuçlar değerlendirildiğinde; yapılan analiz sonuçlarına göre, meslek etiği algısı bağlamında ankete katılan meslek mensuplarının kıdem durumuna göre dürüstlük, tarafsızlık, mesleki yeterlilik ve özen, gizlilik ve mesleki davranış boyutunda anlamlı bir görüş farklılığı göstermediği ancak, genel etik algısı boyutunda, mesleki kıdem durumuna göre, 1-5 yıl ile 16 yıl ve üstü kıdemli meslek mensupları arasında alt ölçek puan ortalamalarının anlamlı farklılık gösterdiği tespit edilmiştir. Buna göre, 1-5 yıl kıdemi olan meslek mensuplarının genel etik algısı, 16 yıl ve üzeri faaliyet gösteren meslek mensuplarına nazaran düşük olduğu gözlemlenmiştir. Bu durumda, kıdemi az olan meslek mensuplarının başta olmak üzere diğerlerine de meslek etiği eğitiminin verilerek etik farkındalık seviyesinin artırılması yararlı olabilir. Bu eğitimler üniversite ve muhasebe odaları işbirliğiyle koordineli olarak verilebilir. Bu şekilde meslek mensuplarının mesleki etik algısı işin daha başından itibaren yükseltilebilir.

\section{KAYNAKLAR}

Akın, Osman- Özdaşl1, Kürşat, (2014). "Muhasebe Meslek Mensuplarının Mesleki Faaliyetlerinde Uymaları Gereken Etik İlkelere Uyma Düzeyine Yönelik Meslek Mensupları İle Meslek Yüksek Okulu Muhasebe Bölümü Öğrencilerinin Algıları”, Muhasebe ve Finansman Dergisi, Temmuz 2014, s.59-73.

Altınkurt, Yahya- Yılmaz, Kürşat, (2011), "Öğretmen Adaylarının Öğretmenlerin Mesleki Etik Dışı Davranışlar ile İlgili Görüşler”, Mehmet Akif Ersoy Üniversitesi Eğitim Fakültesi Dergisi, 11 (22), 113-128.

Arbak, Yasemin, (2010), "İ̧sletme Çevresi ve Muhasebe Etiği İlişkisi” 2. Muhasebe Etik Kongresi, Yaşamda ve Meslekte Etik, TURMOB Yayınları-380, 20 Şubat 2010, İstanbul, s.40-45.

Berkman, Ümit, "Muhasebe Meslek Etiği”, (2010), 2. Muhasebe Etik Kongresi, Yaşamda ve Meslekte Etik, TÜRMOB Yayınları-380, 20 Şubat 2010, İstanbul,s.17-23.

Bilen, Abdulkadir- Yunus, Yılmaz, (2014), "Muhasebe Mesleğinde Etik Ve Etikle İlgili Çalışmalar”, Dicle Üniversitesi İktisadi ve İdari Bilimler Fakültesi Dergisi C:2 S:6 Yaz 2014 s.57-72

Güney, Salih, (2004), Açıklamalı Yönetim - Organizasyon ve Örgütsel Davranış Terimleri Sözlüğü, Siyasal Kitabevi, Ankara.

Biçer, Ali Altuğ- Gündoğdu, Seher, Editörler: Masum Türker, A.R. Zafer Sayar (SMMM), TÜRMOB Yayınları :457)

Kısakürek, Mustafa- Nesrin, Alpan, (2010), “ Muhasebe Meslek etiği ve Sivas İlinde Bir Uygulama”, Muhasebe ve Finansman Dergisi, Say1 47, s.213-228.

Köse, Mehmet Ali- Çetin, Bektaş, (2007), İş Etiği ve Rekabet Stratejileri Yönetimi, Gazi Kitabevi, Ankara. 
Landry, Raymond- Moyes, Glen D- Cortes, Angelica C. (2004), "Ethical Perceptions Among Hispanic Students: Differences by Major and Gender," Journal of Education for Business, 80/2.

Pehlivan Aydın, İnayet (2002), Yönetsel Mesleki ve Örgütsel Etik, PEGEM Yayınevi, Ankara.

Sakarya, Şakir- Kara, Suat (2010), “Türkiye'de Muhasebe Meslek Etiğine Yönelik Düzenlemeler ve Meslek Mensupları Tarafından Algılanması Üzerine Bir Alan Araştırması", Karamanoğlu Mehmetbey Üniversitesi Sosyal ve Ekonomik Araştırmalar Dergisi, Cilt:12, Sayı:18, s. 57-72.

TÜRMOB, "Serbest Muhasebeciler, Serbest Muhasebeci Mali Müşavirler ve Yeminli Mali Müşavirlerin Mesleki Faaliyetlerinde Uyacakları Etik İlkeler Hakkında Yönetmelik”, 19 Ekim 2007 tarih ve 26675 sayılı Resmi Gazete

TÜRMOB, 3568 Sayılı Meslek Yasası ve Son Değişikliklerle Yönetmelikler, TÜRMOB yayınları-330, Ankara.

Yalçın, Selçuk, (2011), "Muhasebe Meslek Mensupları ve İşletmelerin Etik Konusunda Tutumları: Türkiye Araştırması”, Muhasebe ve Finansman Dergisi, Ekim 2011, s.4766.

Yıldız, Gülsevil, (2010), "Muhasebe Mesleğinde Meslek Etiği Ve Kayseri İl Merkezinde Bir Uygulama”, Erciyes Üniversitesi İktisadi ve İdari Bilimler Fakültesi Dergisi, Sayı: 36, Ağustos-Aralık 2010, s.155-178.

Yüksel, Mehmet, (2002), "Modernleşme Bağlamında Hukuk ve Etik İlişkisine Sosyolojik Bir Bakış”, Ankara Üniversitesi SBF Dergisi, 57 (1), 177-195.

http://tr.wikipedia.org/wiki/Etik, (22.07.2014)

http://www.turmob.org.tr/MBS/MecburiMeslekKararlari.aspx. (23.07.2014)

http://www.kgk.gov.tr/contents/files/Pdf/KGK_Brosur.pdf. (23.07.2014)

http://www.kgk.gov.tr/contents/files/KGK_Faaliyet_Raporu_2012.pdf (23.07.2014)

http://www.turmob.org.tr/TurmobWeb/Attachment.aspx? param=TDLPfWtFdrm1e8Dlv7FNO oH6uk4KIkiU9mRFMeskCPG6O606XtOBzMOW0SM81//gowKqVpD7XHUTiz1lrj Y74w ( 24.07.2014)

http://www.mufad.org/journal/attachments/article/108/16.pdf.

http://www.turmob.org.tr/TurmobWeb/Attachment.aspx?param=+quFU/yYHWdwJaon/dnM E6Y1501D88YO4bmoEImj1+VTHPHoVyJkAIWhSoDMjzc8+fHxrptS2QE $(01 / 11 / 2014)$

http://www.kgk.gov.tr/contents/files/Pdf/BagimsizDenetcilerIcinEtikKurallar04062014.pdf $(03 / 11 / 2014)$ 
http://www.asmmmo.org.tr/userfiles/others/files/Mvzt/Ynt/3568/12.pdf

(Erişim tarihi: 03/11/2014).

http://www.tmud.org.tr/Files/Etik\%20Kur\%20El\%20Kit.\%202013.pdf

(Erişim tarihi:03/11/2014) (Muhasebe Meslek Mensupları İçin Etik Urallar El Kitabı 2013 Çevirmenler: Yıldız ÖZTÜRK (Baş çevirmen), Dr. İpek TÜRKER (SMMM), 
